\title{
Transforming ABC Co- Through Lean Management \& Agile Manufacturing
}

\author{
Prof H N Singh \\ Professor, Management, IMS, Noida \\ A8B, sector 62, Noida, UP
}

\begin{abstract}
ABC co. was established in Delhi in 1980, which produced electrical switchgears \& appliances. The company had manual operations initially; quality was not a thrust area having about $16 \%$ process rejections. The demand for electrical appliances/switchgears was rising with increase in urbanization/ construction activities. The warranty return was as high as $6 \%$ and more competitors entered in the market making it difficult to improve sales.
\end{abstract}

After brainstorming session, management implemented various techniques of TQM tools (5S, SQC, TPM, etc.). Investment in new technology including installation of few new machines and few low cost automation of equipment was made. $\mathrm{ABC}$ co. expected the payback period of three years for the new installed capacity. The internal rejections came down and as also cost and thereby market demand rose significantly.

The major contribution was: a) Improving quality, b) Inventory reductions, c) BOM cost reduction, d) reduced order to supply time.

Keywords: Warranty returns, TQM, Quality, Inventory, Vendor up gradation, Agile manufacturing, Lean Manufacturing.

\section{INTRODUCTION}

Mr. A B Chand, presently Chairman of ABC Company ( $\mathrm{ABC} \mathrm{co}$ ), thought of starting one dealer shop of electrical products in Chandini Chowk, Delhi in early seventies. From experience of small dealer of various brands of electrical cables, switches, starters, changeovers etc. he ventured into manufacturing and established a production unit of such items in 1983, in Kirtinagar, then in Tilaknagar and later in Samepur, Badli. ABC co was established in 1983 in Delhi in collaboration with French MNC (Multinational Corporation). There was no looking back from 1983 when they set up units in Faridabad and later in Sahibabad for energy meters, switches and starters. This was the time when management of the company was gradually shifting its focus from a family owned (for ten years) to professionally driven organization. Most of the professionals were recruited from 1996 onwards in all major functional areas viz, marketing, production, factory operations, quality control and financial management. ABC Co was popular in Northern India for electrical requirements. It has been slowly growing in terms of sales and footprints across all the four regions in India.

\subsection{Manufacturing Progress Crisis Ahead}

$\mathrm{ABC}$ co reached a production level of 8000 nos. of MCBs (miniature circuit breakers) per day, turnover of around Rs 1.50 crores/month in year1990. The company was operating in single shift basis having about 400 workmen and supervisory staff of approx. 10 in number. The company could work in all the three shifts producing 25,000 MCBs per day. The method of assembly was manual. The manufacturing capacity for components was more than 25000 nos. per day, mostly with the help of in-house power presses, welding machines, testing equipment which was more than 12 years old.

The inspection and testing method was also manual and $100 \%$ inspection in all stage was 
necessary. The vendor based on component and sub-assembly was limited to local manufacturers. The machines being used were mostly manual or jobbing type. Quality level was not up to mark, having about $18 \%$ internal rejections and around $7 \%$ warranty returns, which was major crisis and hence challenge to management.

\subsection{Concerns}

\section{Market Conditions}

The requirements for electrical products were rising with increase in urbanization/ construction activities. ABC co had a large network of dealers (300) across India. This high warranty return of $7 \%$ came in way of improving sales by dealers, which was in fact, highlighted in annual meetings with top management. Gradually more competitors entered in the market, making selling still difficult.

The market size was expanding due to industrialization and economic growth, the top management and investors were looking forward to exploit same. There was growing apprehension that the gap between the increasing requirements and lesser manufacturing capacity utilization may become advantage to foreign brands entering India at that time. This has all the more put pressure on factory operations to improve capacity utilization, better quality \& faster delivery at competitive rates to the market.

\section{Internal Conditions}

As the competition was increasing, ABC co had concerns in operations which may be emphasized as below.
a. Low production volume
b. Poor quality vendor supplied materials
c. High internal and market rejections
d. High inventory of $\mathrm{rm}$ ( raw material)

\subsection{Literature Review}

In order to address issue of poor quality of incoming materials from vendors, it can be argued that scholars in last two decades have identified variety of measures and parameters to select, assess and upgrade vendors respectively. Chan (2003) has cited seven performance measures as the key elements of vendor selection: cost, resource utilization, quality, flexibility, visibility, trust and innovativeness. For each performance measure, he identified factor (parameter) commonly used for vendor selection. Sarode et al. (2008) identified total 11 qualitative and quantitative measures (1) quality, (2) visibility, (3) trust, (4) innovativeness (5) flexibility and responsiveness, (6) resource utilization, (7) cost and asset, (8) technological capability, (9) service and (10) time to market and (11) delivery reliability. Apart from these 12 measures, a total of 58 items/variables were identified. Yet another scholar Wang et al. (2005) recommended four measures (1) delivery, (2) reliability, (3) flexibility and responsiveness, and (4) cost and asset with 12 other parameters, related to vendor selection. Another scholar Noorul and Kannan (2006) declared seven performance measures (1) quality, (2) delivery, (3) production capability, (4) service, (5) engineering/technical capabilities, (6) business structure and (7) price, for vendor selection. Sha and Che (2005) recommended 4 performance parameters: price, matching, delivery and quality for virtual integration with multi-criteria vendor selection. Supply Chain Council's SCOR model (2006) international standard establishes four measures and 12 parameters for selection of vendor.

The issue of high process and marketing rejections are normally attributable to lack of conformance to quality standards cited by many schcolars.TQM is one philosophy which address most of quality issues of organisations. TQM means a broad set of management and control processes designed to focus an entire organization including employees on providing products and services that do the best possible job of satisfying the customer (Talha, 2004). TQM also means that the organization's culture, which is defined by, and supports the constant attainment of customer satisfaction through an integrated system of tools, techniques, and training. Recent academic advances in this direction justify that TQM directly as well as indirectly affects inventory, quality, productivity and financial performance of the organizations (Kaynak, 2003). However, the effect of TQM on operation performance is rarely researched. In most cases, scholars seem to be taking an overall organizational view, rather than operations performance itself. Kaynak (2003) has justified that quality management practices enhance not only the quality performance, but also 
the inventory performance. Reference to Dr E Demings's 14 principles is the right step in resolving process and product non-conformances. Also, in his research it is found that quality performance increases the financial and market performance of an organization.

Inventory of $\mathrm{rm}$ is required to be processed it at right time for delivery of FG (finished goods) to customer as and when demanded. Many researchers have done commendable work to guide on size of inventory depending on various factors including customer demand, type of industry, and size of operations. Organizations depend heavily on vendors and must strategize to have close partnership with suppliers (Sahay et al, 2006), where VMI (Vendor managed Inventory) plays major role in such integration (Borade and Bansod, 2010).In VMI practices vendor also performs planning, production, purchasing, logistics, forecasting, which is possible with the help of electronic information sharing through EDI (Fawcett et al., 2005). Indian organizations in SMEs sector in particular are shy of such EDI integration. In contrary few researchers observed that VMI benefit small companies more (Kuk, 2004).The reasons, strategies, barriers be studied before adopting VMI in an organization. What is implemented must be measured, otherwise it will not get implemented. Some researchers observed that (Saad and Patel, 2006, Sharma et al, 2008) that Indian industries have not adopted SCM including VMI except few progressive organizations, like automobile sector where adoption of these techniques are bearing fruits.

\subsection{Objective}

To study the crisis related to supply chain issues including process and product quality, at $\mathrm{ABC}$ co, and find solutions by:

1) Analysing the problem

2) Upgrading and improving internal processes \&

3) Vendor's processes.

4) Establish model framework for agility in $A B C$ $\mathrm{CO}$ for benchmarking

\subsection{Research Methodology}

This paper is case study based on the problems confronted by ABC Co. Author along with associates were invited by managing director of
$\mathrm{ABC}$ Co to study problems, find its causes and recommend implementable suggestions. Steps followed were as under:

- Identifying reasons of problems(concerns) by establishing a framework on case study

- Practical analysis

- Theoretical analysis

- Giving recommendation for finding solutions to major concerns

- Implementations to be carried out by management.

\section{CONCEPTUAL FRAMEWORK}

The manufacturing companies are concentrating primarily on reduction of cost of materials used for making final product, also known as finished product. The cost reduction cannot always be manufacturer driven as the price of each material is dependent on market factors e.g. demand, international scenario, currency fluctuations etc. Nevertheless the pressure of competition and to remain in demand, the manufacturing companies still will have to device means to reduce or maintain the price of finished product. In this regard lean management or lean manufacturing previously known as TPS or JIT coined by Kiichiro Toyoda( ) has attracted academicians across the world. It's generally agreed that overall goal of JIT should not only be to reduce inventory but reduction in time from customer order to delivery by elimination of waste throughout the system.

Lean Manufacturing affects almost every aspect of production and business process. Delivery of material to be on time is taken for granted by industries honcho as well academicians or researchers. Lot of literature suggests( Shingo, Shigeo ,1989: James-Moore, S.M. and Gibbons, A.1997, Perry ,James H.,1988 ), that more emphasis is being given to JIT supply logistics strategies as well. Agile manufacturing is a term applied to an organization that has created the processes, tools, and training to enable it to respond quickly to customer needs and market changes while still controlling costs and quality (Wikipedia.org.in, retrieved on 21.7.12).

Agile manufacturing is ahead of Lean manufacturing in the evolution of production 
methodology. The key difference between the two is like between a thin and an athletic person, agile being the latter. In manufacturing parlance being both is often referred to as leagile. According to Martin Christopher, when companies have to decide which way to go about, they have to look at the Customer Order Cycle (COC), the time the customers are willing to wait and the lead time for getting supplies. If the vendor has a short lead time, lean production is possible. If the $\mathrm{COC}$ is short, agile production is beneficial.

Manufacturing industry is on the verge of a major paradigm shift, which will take progressive organizations away from mass production, way beyond lean manufacturing, into a world of agile manufacturing (Kidd, 1994). As new manufacturing enterprises are marked by ability to effect flexible remodeling of resources, shorter cycle times and quick responses to customer demands, agile manufacturing (AM) has been spontaneously evolving from lean manufacturing. This hypothesis envisages that the organization, people and technology can be combined into an integrated and coordinated stuff without compromising the cost and profitability (Kidd, 1994; Vinodh et al., 2010). In contrast, Krishnamurthy and Yauch (2007) and Goldman et al. (1995) believe that agile manufacturing company is an organization that demonstrates the ability to thrive and reconfigure itself in a dynamic, aggressively change embracing, and growth oriented environment. Accordingly, AM can be considered as a structure supported by three essential elements:

- $\quad$ innovative enterprise management patterns

- $\quad$ skill based knowledgeable people, and

- flexible and intelligent IT/IS (Information Technology /Information systems).

Finally, ERP systems accompanied by appropriate enterprise management forms could assist the manufacturing to achieve agility via merging above three resources into a coordinated and interdependent system. Despite the statement by Harrison (1997), that lean and agile manufacturing are often placed as opposing and incompatible paradigms toward different end objectives, Katayama and Bennett (1999) and Goldsby et al. (2006, pp. 61) support these two strategies share some commonalities, that is, meeting customer demands at the least total cost, and should not be viewed as competitive, rather as mutually complimenting. Consequently, Naylor, Naim, and Berry (1997) coined the advanced concept 'Leagile' manufacturing to refer to hybrids of the lean and agile manufacturing systems. Lean manufacturing approaches the upstream(vendor driven) of supply chain side to drive down costs associated with cost-leadership strategy (Hallgren and Olhager, 2009), while agility approaches the downstream(customer oriented) to exploit profitable opportunities in a volatile marketplace (Mason-Jones et al., 2000) with sufficient flexibilities.

Based on literature review, conceptual framework and the methodology explained the steps to address the issues of reduce warranty returns, internal process rejections, poor vendor supplied materials, high cost of product can be taken by adopting modern management tools such as TQM ,LM,AM in many ways including those given below:

- $\quad$ Reducing cost of input raw materials

- Reducing weight/ content of materials by redesigning Reengineering process using TQM philosophy

- Reducing the manpower cost by productivity improvements

- $\quad$ Reducing inventory of raw materials and work in progress by best $\mathrm{scm}$ (supply chain management) practices

- Reducing stocks of finished goods in ware house by better delivery \& logistics systems

With this background this case study has been developed based on manufacturing organization $\mathrm{ABC}$ co, to find solution to the crisis the company was in.

\section{3. CONCERNS}

It's quite difficult to have same variables, parameters for vendor assessment and their up gradation (upstream side) and its relative significance to be uniform in all industries in all sectors. Hence heterogeneous data will give 
erroneous effect if adopted for generalized use in different industries. Based on literature review, author's experience in many industries (Hind Motors Itd, ITI Ltd, Havells India Ltd, and Rinac India Ltd) and academic exposure, due diligence and discussion with directors of $\mathrm{ABC} \mathrm{Co}$, it was decided to consider ten parameters namely:

1. Quality

2. Costs,

3. Delivery Reliability

4. Service

5. Capacity

6. Flexibility \& responsiveness

7. Human Factor

8. Technology

9. Innovation

10. Other factors for vendor assessments.

In the present case a sample case of three vendors out of 85 vendors of $\mathrm{ABC}$ co have been considered for explaining the approach (Methodology) adopted supplying BOM (bill of materials) components and other raw materials. Similar exercise had been adopted by the company later on for all vendors' assessment, their grading and consequent up gradation.

\section{Management Intervention}

The management at the level of Board of Directors has been demanding professionals in factory operations to perform on certain measurable parameters e.g.:

1. BOM cost

2. RM and FG inventory in terms of no of days of sales (DOS)

3. Percentage of lots of RM rejected in receipt inspection stage.

4. Percentage of BOM cost lost in line rejections due to poor workmanship and many more.

These measurable parameters are worked out after brainstorming in major functional areas. The above parameters are important for reducing cost of inwards $\mathrm{rm}$ and also the cost of processing then only the overall cost of manufacturing could be controlled. Thus the key result area (KRA) of materials management, marketing and production department can be defined, summarized to monitor, control and improve continuously for adopting lean management(LM)and agile manufacturing(AM), as given below. a) Why Enterprise resource planning (ERP):

It is extremely complex to control cost of over 189 verities of rm including its timely supply to maintain smooth inflow for planned production, the top management discussed with service providers, materials management, marketing and production heads and decided to implement the ERP systems for effective, timely, accurate production planning and materials management. Everyone's involvement in agreeing that ERP will help solve all complex issues in materials management, production planning is of paramount importance which will facilitate data entry and retrieval live from production, marketing, quality, SCM, finance departments etc. This will be suitably reflected in working capital management, funds management, P \& L (profit and loss $\mathrm{a} / \mathrm{c}$ ) accounts managements. ERP will support effectively strong supplier base towards quality improvements, cost reductions, and enhanced delivery performance thus maximizing supplier performance better than competitors [Davis (1994), Monczka (1990)].

b) Adopting TQM:

After implementation of ERP the significant contribution can be realised in terms of inventory information and slight reduction of inventory. But this may be insignificant as size of company keep increasing from few tens of cores of production and sales per year to few hundreds of cores of production \& sales per year product verticals wise and as also unit wise. The company may require second round of major brainstorming both at executive and BOD (board of director) levels when TQM philosophy are introduced. The systems of ERP \& technology alone did not yield continuous result without inculcating ownership feeling, rewarding outstanding employees, following $\mathrm{Dr}$ Deming's' principles. Indian manufacturing sectors including $\mathrm{ABC} \mathrm{CO}$ also implemented TPS (Toyota Production Systems), 14 principles of Dr Deming (1982) and many features of TQM ( Total quality Management) [Walton and Mary(1986)], philosophy for QIPs (quality improvement programs ), step by step small improvements, Kaizen, initiated by people on job and workmen on shop floor too [Mohanty 
and Deshmukh (1993),Levy et al (1995)].TQM initiatives among others also include lean manufacturing [Ohno, Taiichi (1995),Shingo, Shigeo(1989), Womacck et al (1991)] and JIT( just in time) [Cook R L and Rogowski (1996), Golhar, Stamn \& Smith ( 1990)] making considerable impact on supply chain effectiveness there by profitability of organizations

The major steps to reduce inventory of raw materials amongst others can be:

1. Vendors classifications

2. Vendors need identifications

3. Vendors quality systems

4. Vendors financial conditions

5. Vendors volumes levels

6. Vendor's willingness and many more.

Here follows a brief description of basic set of Total Quality Management tools. Out of many quality tools of TQM quite essential for business transformations. Few are described as given below:

\section{b1) Kaizen}

Kaizen is small improvements and a change for better. It must be accompanied by change of method. The Kaizen concept stimulates productivity improvement as an ongoing process in any company. It is a practice oriented strategy which leads to creation of culture of improvement it is more a way of life or at least a cultural approach to quality improvement. The implementation of philosophy of Kaizen can be achieved through involvement of employees to effect improvements. By practicing Kaizen culture, managers demonstrate commitment to quality. Also, the workers with adequate support from managers become a major source of improvement .Kaizen system is simple, but its implication are far reaching as also explained by CII through their supported site, (www.Kaizen Eye.com Retrieved on 21.7.12), which can be in the area of Productivity, Quality, Cost, Delivery, Safety \& Morale of Employees. Popularly called "Lean Guru" and the inventor of Continuous Improvement (CI) Masaaki Imai has been a pioneer and leader in spreading the Kaizen philosophy all over the world. His book, Kaizen: The Key to Japan's Competitive Success (1986) was quickly accepted by scholars, industry alike: firmly embedding the word Kaizen in the corporate glossary. 'Gemba Kaizen: a Commonsense, Low-cost Approach to Management (Masaaki Imai,1997) which uses relevant case studies to detail 21 practical kaizen management practices aimed to achieve greater productivity, better quality and more profits with minimal cost and time.

In the mid-eighties Mr. Imai brought this message to executives of the leading North American carmakers. To acknowledge due recognition to Kaizen philosophy, Kaizen Institute was established (Masaaki Imai, 1985) in Japan, also now known as Kaizen Institute Consulting Group (KICG). The Institute focuses on a top-down and bottom-up approach that engages the entire enterprise to create a Lean culture that is sustainable. Kaizen Institute supports organizations of all sizes in Europe, Asia-Pacific, Africa, Middle East and the Americas, in all business sectors. It provides broad consulting, training and certification (Kaizen College), and benchmarking services.

b2) $5 S$

$5 \mathrm{~S}$ is the name of a workplace organization method that uses a list of five Japanese words: seiri, seiton, seiso, seiketsu, and shitsuke.

- Sorting (Seiri): Eliminate all unnecessary tools, parts, and instructions. Go through all tools, materials, and so forth in the plant and work area. Keep only essential items and eliminate what is not required, prioritizing things per requirements and keeping them in easily-accessible places.

- Stabilizing (Seiton): There should be a place for everything and everything should be in its place. The place for each item should be clearly indicated.

- Sweeping or Shining (Seiso): Clean the workspace and all equipment, and keep it clean, tidy and organized. At the end of each shift, clean the work area and be sure everything is restored to its place. An important point is that maintaining cleanliness should be part of the daily work.

- Standardizing (Seiketsu): Work practices should be consistent and maintained. All 
work stations for a particular job should be identical.

- Sustaining the Practice (Shitsuke): Maintain and review standards. Once the previous $4 \mathrm{~S}$ 's have been established, they become the new way to operate. Train and maintain the standard.

The standard model of $5 \mathrm{~S}$ has been explained by many scholars and organizations, e.g.www.tqmi.com (Retrieved on 21.7.12)

b3) Statistics exposes problems: Statistical methods can be used for summarizing or describing a collection of data; this is called descriptive statistics. This is useful in research, when communicating the results of experiments. In addition, patterns in the data may be modeled in a way that accounts for randomness and uncertainty in the observations, and are then used for drawing inferences about the process or population being studied; this is called inferential statistics. Descriptive statistics and the application of inferential statistics or predictive statistics together comprise applied statistic as explained by Wikipedia.org (retrieved on 21.7.12). Descriptive statistics are used to describe certain quality characteristics, such as the central tendency and variability of observed data. Although descriptions of certain characteristics are helpful, they are not enough to help us evaluate whether there is a problem with quality. Acceptance sampling can help us do this. Acceptance sampling helps us decide whether desirable quality has been achieved for a batch of products, and whether to accept or reject the items produced. Although this information is helpful in making the quality acceptance decision after the product has been produced, it does not help us identify and catch a quality problem during the production process. For this we need tools in the statistical process control (SPC) category.

\section{Statistical Quality Control (SQC)}

Quality control charts are chronological graphs of process data that, although based in statistical theory, are easy for practitioners to use and interpret. These charts also can help users to develop an understanding of the performance of a process and to evaluate any benefits or consequences of process interventions. Use of statistics in these charts was first used by Dr
Walter Shewhart (1924).Some scholars believe strongly that SQC application is essential for control of all process, Benneyan James c(1998).

Statistical process control (SPC) involves inspecting a random sample of the output from a process and deciding whether the process is producing products with characteristics that fall within a predetermined tolerance range Statistical Process Control (SPC) is a control mechanism whereby measurements of product quality are actively obtained and charted simultaneously as industrial products are produced. Control is obtained when a statistical measurement such as means of a group of products are within certain control limits drawn on the statistical process chart. For these charts, there are certain set of rules to follow that will tell the technicians when a process may be out of control. When these conditions are observed, the technicians are expected to stop the manufacturing process so that corrective actions can be taken. (Dougles .C. Montgomery, 2003). SPC answers the question of whether the process is functioning properly or not. If process is having process capability above 1.3 , the process is said to be under control There are seven commonly recognized tools or diagrams, popularly known as 7Q C Tools, quoted in an exercise by a scholar (Fred Spring, 1995), for statistical process control:

1. Check sheet

2. Run chart

3. Histogram

4. Pareto chart/principle

5. Scatter diagram

6. Cause and effect or fishbone diagram

7. Control chart.

Acceptance sampling is the process of randomly inspecting a sample of goods and deciding whether to accept the manufactured entire lot based on the results. Acceptance sampling determines whether a batch of goods should be accepted or rejected. There are two types of sampling based on character of a product or process to be assessed.2a) Inspection by Variables: Sampling, measurements based on parameters which are varying but measurable, e.g. diameter of a rod, height of students in a class etc. Also called sampling plan or inspection by variables.2b) Inspection by Attributes: Sampling 
or measurements based on attributes, incidence where measurement is not possible ,but can be said to be OK or Not OK or good or bad etc. This type of inspection is called as inspection by attributes. Many modern high-reliability auto products are designed to operate without failure for a very long time. Life testing for these products under use conditions takes a lot of time to obtain reasonable data on. For such situations sampling plans based on such life tests are impractical. Introducing accelerated life tests (ALTs) in life-test sampling plans will be right method to overcome such difficulty. Wallace (1985) and. Sang Wook Chung, et al, (2006),"stressed the need for introducing ALTs to the future plans of MIL-STD-781(Military Standard, USA).

c) Systems of QMS \& EMS

All organizations must focus on building quality management systems conforming to International Quality management Standards e.g. ISO 9001(www.iso.org/iso/iso_9000, retrieved on 24.7.12). The organization sets its quality policy, vision, mission, appoints MR and implements ISO 9001.The systems implementation is then audited and certified by third party certifying agency e.g. BIS, BSI, TUV, etc. This certificate is valid for three years. Organizations also endeavors taking up environmental care \& its protection by conforming to Environment Management Systems(EMS),ISO 14001, (www.iso14001.org.uk, retrieved on 24.7.12) and getting certification by certifying agencies as mentioned above, valid for three months. . The certification builds brand image of company i.e., getting more market orders, having joint venture partners, finance from institutions etc.

d) Lean Management or manufacturing $(L M) \&$ Agile Manufacturing (AM):

The manufacturing sector is considered a driver to create social sustainability, through direct and indirect employment, and economic sustainability, through economic growth (Manufacture, 2004). R\&D programs and roadmaps, at international and national level, are pushing manufacturing sector to go towards new technological solutions, new approaches and new paradigms such as EC (2007a, b, 2008, 2009a, b, 2010, 2011), National Science and Technology
Council (2008). Sustainable manufacturing, ICTenabled intelligent manufacturing, high performance manufacturing, and exploiting new materials (taking advantage of new materials/technologies) through manufacturing (EFFRA, 2010) are some examples of R\&D program domains. Intrinsically to these domains, there is an implicit management philosophy; an analysis is presented about how the two management philosophies for manufacturing, namely, agile manufacturing and lean manufacturing, are addressed.

Lean manufacturing is a system based on the philosophy of waste elimination, the removal of all non-value added activity from the process of delivering a customer's requirement in a manner that delights the customer and ensures they return with repeat orders. Most customers use the metrics of price, quality, on-time delivery, and availability of required quantity with which to measure the performance of a supplier. Lean manufacturing systems operate on a continuous improvement philosophy based on the removal of waste from the system in order to maximise the potential of these four order-winning criteria (Hill, 1993, p. 42). This philosophy is supported by the reduction of set-up times to allow the economic production of small quantities (Booth, 1996).

Lean manufacturing deployment: The only proven manufacturing model to have constantly reduced the lead time for new products is lean manufacturing as practiced in the automotive industry. In aviation sector as well for example, Airbus Industries is well placed to take advantage of lean manufacturing with the introduction of the A318, A340-500/600 and the future A3XX. Boeing meanwhile appears to have recognized the weakness of its old manufacturing systems and during 1997 was halfway through the modernization of its manufacturing, design and inventory management systems (Skapinker, 1998 Phillips, Mark1999,). First book by Masaaki Imai introduced the 'LEAN' philosophy to the world, followed by another book 'The Machine That Changed the World: The Story of Lean Production' (Masaaki Imai, 1990). Masaaki Imai's first-hand account is based on his close associations and travels with such Japanese corporate dignitaries as Shoichiro Toyoda and 
Taichi Ohno and reveals the secrets behind the success of Toyota and other Japanese companies.

There is fragmented evidence throughout the aerospace industry that companies are now adopting the lean production philosophy and system. This is particularly true of companies that have strong ties with the automotive industry, Lucas Aerospace of the Lucas Varity group being a prime example. To support this evidence some research into the applicability of lean manufacturing and its deployment within the aerospace industry has been performed. JamesMoore and Gibbons (1997) cover this field of research to some detail in the paper titled, "Is lean manufacturing universally relevant? An investigative methodology". For the investigation they defined a typical case model representative of a lean automotive producer. From this model six core processes were identified (James-Moore and Gibbons, 1997). These core processes being:

1 new product introduction, 2 manufacturing, 3 logistics, including purchasing, 4 sales and marketing,5 product support, 6 people management.

From this process model five key characteristics were established with which a lean producer would improve its business (James-Moore and Gibbons, 1997). These characteristics being:

1 flexibility, 2 waste elimination, 3 optimization, 4 process control, 5 people utilization.

Lean manufacturing is all about the elimination of waste from the value chain (Womack and Jones, 1996). This system has already been proven to delight customers, the metrics of the customer being their own order-winning criteria of price, quality, on-time delivery and availability (. This is supported by investigations and resulting analysis of findings by some academics (James-M Mark Phillips, 1999, Moore and Gibbons, 1997). In addition to this research Womack and Jones (1997) cover extensively the transition of a traditional manufacture to that of a lean manufacture in their detailed case study of Pratt and Whitney.

Agility has been expressed in different ways. In one way it has been introduced as a total integration of business components (Kidd, 1995). In another way it has been represented as flexibility of manufacturing, people and organization (Montgomery and Levine, 1996 ). Moreover, s o m e other expressions such as concurrency, adaptability, use of information systems and technologies, and diverse combinations of the entire above mentioned have been used in defining agile manufacturing (Kidd, 1995; Booth, 1996; Youssef, 1992).

The organizations can become agile by following the method, based on two main factors (Dove, 1996; Kidd, 1995(1) Responding to changes (anticipated or unexpected or interruptions) in proper ways on time. (2) Exploiting changes and taking advantage of changes as opportunities.

The conceptual model of agility (Zhang and Sharifi, 2000), has three main elements namely:

- Agility Drivers, means changes/pressures from the business environment that necessitate a company to search for new ways of running its business in order to maintain its competitive advantage;

- Agility Capabilities. the essential capabilities that the company needs to possess to be able to respond to and take advantage of the changes; and

- Agility Providers that is the means by which the so-called capabilities could be obtained.

As challenge of changes and pressures faced by companies may vary, the extent of agility required by individual companies will be different (James-Moore, 1996). This degree(extent) is defined as the "agility need level", which is a function of factors such as instability of the business environment, the business environment, and the organization culture of the company itself (H. Sharifi, Z. Zhang, 2001). Once the agility need level is determined for a company, the next step is to assess the current agility level of the company, i.e. how agile the organization is. The difference between the level of agility required and that the organization already possess will be compared, analyzed to provide a basis for further decision making.

AM was developed as a response to Lean Manufacturing (LM) systems (Custom Cable, 2010). LM systems are based on the need to create value for the customer as process 
improvement occurs. LM solutions often lead to standardization of best practice and streamlined flow. Through the study and analysis of customer demand, LM derives solutions through continuous improvement as iterations of value development. Hence, LM requires a cycle of improvement, known as the Stewart cycle of Plan-Do-Check-Act (Deming, 1967), whereas AM is not constrained to such protocols.

According to McCullen and Towill (2001), as cited by Pham et al. (2008), AM is a successor of LM because there are some concepts of LM that are adopted by AM. For instance, one of the most popular principles adopted by AM from LM is the pull system. Pull systems means that the company will not produce a given product unless an order is placed by a customer, reducing onhand inventory. AM functions in the same way as LM does, but it does so by focusing on market demand, rather than on planning, as a generator of production quotas. The literature taken in account to this review is not an exhaustive material on the two concepts, but nevertheless some general differences between the two and also their origins are presented.

\section{ANALYSIS OF PRESENT RESEARCH: STEPS TAKEN}

To address the crisis managing director desired factory head and marketing heads to jointly work out strategies as outlined in methodology. As a result of brainstorming in early 2001, ABC co started quality drive including vendor up gradation, with employee involvement to bring down rejections, raw materials inventory levels and reducing non value added activities .Marketing people were given separate responsibility of controlling the inventory of finished goods without sacrificing delay in delivery of $\mathrm{fg}$. No of corrective and preventive steps taken to address the problems of $\mathrm{ABC} \mathrm{CO}$ are as under:

a) Restructuring: Quality department was revamped in year 2002 introducing quality systems conforming to ISO 9001. No of non performing personnel including workmen were removed if they failed to improve. Another team was formed which started recruiting 100 semi- skilled and unskilled workers. Training was given to them. Despite that, internal rejections went on increasing. Simultaneously, warranty returns did not come down.

b) TQM Implementations: As a result of another brainstorming session in early 2003 various advanced techniques of TQM (total quality management) tools like Kaizen, 5S, SQC, TPM (Total Productive Maintenance), etc. were implemented. Total Productive Maintenance, shortly termed as TPM, is the concept originated and developed by Japan Institute of plant Maintenance (JIPM) Tokyo, since late sixties. JIPM-TPM is the key for the operational excellence for many Japanese companies.TPM means to achieve high level of productivity, through total participation of all people inside the organisation and then developing self -managing abilities in people and practices. Productivity, in JIPM-TPM means increasing production and reducing cost simultaneously.TPM is based on zero-loss concept viz., zero break downs, zero accidents, zero defects etc., primarily to achieve high reliability/flexibility of equipment and reduce costs through minimizing wastage of man hours, raw material, power, tools etc. (Retrieved from www.tpmclubindia.org, on 24.7.12)

SGA (Small Group Activities) were initiated amongst the workmen for controlled conditioned experiments on problems confronted by workmen on shop floor. To improve implementation of TQM tools few engineers and supervisors were recruited. They started demanding better productivity, quality from workers and asked them to improve to the desired level of quality acceptance. Low cost automations(LCA)were introduced in major processes to bring consistency and higher productivity.LCA is a technology that creates some degree of automation around the existing equipment, tools, methods and people, using mostly standard components available in the market( retrieved from www.iitb.ac.in on 25.7.12) c)In-house Manufacturing Rewamp:To improve the in-house component manufacturing quality \& vendor supplied components, a software known as RqMan, developed by WCdr Keith, was installed in year 2004,which used statistical techniques helping reduce the inspection effort by $80 \%$ and conformance quality up to $99 \%$. This software 
automated the process inspection by hand and foot switches, interfacing reducing the manpower. Inspection and production personnel frequently resorted to application of $7 \mathrm{QC}$ tools to solve technical problems and reduced NCPs (nonconforming product).

d) SCM Rewamp:Internal process improvements explained above started giving positive results within two years till 2006, still rejections and wastages were high enough(Annexure1). The management started concentrating on vendor's processes as well.SCM (supply chain management) department was strengthened .New vendors purchase policy was framed including vendor selection, vendor assessment, vendor up gradation. Vendors meet was called for first time in history of company wherein their problems were also understood by purchase managers. Vendors were explained the new philosophy of management, to improve their materials quality to remain competitive together. Vendors were trained in quality, SQC techniques and even supported to get ISO 9001 certification. Within next one year the results were remarkable. The vendor supplied materials conformance started improving remarkable in next three years. From an average $60 \%$ to an average $80 \%$ in this period. (Annexure 2A \& 2B)

\begin{tabular}{|r|l|r|r|r|r|r|r|r|r|r|}
\hline Sn & Mon & 2003 & 2004 & 2005 & 2006 & 2007 & 2008 & 2009 & 2010 & 2011 \\
\hline 1 & Jan & 5.5 & 4.9 & 4.5 & 3.5 & 2.8 & 2.5 & 2 & 1.5 & 1.3 \\
\hline 2 & Feb & 5.6 & 4.7 & 4.5 & 3.5 & 2.8 & 2.5 & 2 & 1.5 & 1.3 \\
\hline 3 & Mar & 5.4 & 4.8 & 4.2 & 3.6 & 2.7 & 2.5 & 2 & 1.5 & 1.2 \\
\hline 4 & Apr & 5.5 & 4.6 & 4.3 & 3.6 & 2.7 & 2.2 & 2 & 1.4 & 1.1 \\
\hline 5 & May & 5.5 & 4.6 & 4 & 3.6 & 2.7 & 2.2 & 1.8 & 1.4 & 1.1 \\
\hline 6 & Jun & 5.7 & 4.6 & 4 & 3.5 & 2.6 & 2.2 & 1.8 & 1.3 & 1.1 \\
\hline 7 & July & 5.6 & 4.7 & 4 & 3.2 & 2.5 & 2.3 & 1.8 & 1.2 & 1.1 \\
\hline 8 & Aug & 5.5 & 4.6 & 3.5 & 3.2 & 2.5 & 2.2 & 1.8 & 1.2 & 1.1 \\
\hline 9 & Sept & 5.5 & 4.5 & 3.5 & 3.1 & 2.5 & 2.1 & 1.8 & 1.2 & 1 \\
\hline 10 & Oct & 5.3 & 4.5 & 3.5 & 2.9 & 2.5 & 2 & 1.7 & 1.2 & 1 \\
\hline 11 & Nov & 5.2 & 4.3 & 3.6 & 2.9 & 2.6 & 2 & 1.5 & 1.2 & 1 \\
\hline 12 & Dec & 5.2 & 4.3 & 3.5 & 2.8 & 2.5 & 2 & 1.5 & 1.2 & 1 \\
\hline & Avg\% & 5.5 & 4.6 & 3.9 & 3.3 & 2.6 & 2.2 & 1.8 & 1.3 & 1.1 \\
\hline & & & & & & & & \\
\hline In 1996 the process rejection was $18 \% \&$ warranty return was $7 \%$. & \\
\hline Rejection has come down from 1996 till2011 by90\% & & & \\
\hline
\end{tabular}

Annexure1: Transforming ABC Co: MCB Process rejection (\%) 


\begin{tabular}{|c|c|c|c|c|c|c|c|c|c|c|}
\hline & & \multicolumn{4}{|c|}{ Year 2003-2006 } & \multicolumn{4}{|c|}{ Year 2007-2010 } & \\
\hline $\mathrm{SN}$ & Results & 2003 & 2004 & 2005 & 2006 & 2007 & 2008 & 2009 & 2010 & \\
\hline 1 & RmInventory in no of Days(DOS) & 60 & 54 & 40 & 30 & 21 & 15 & 12 & 7 & \\
\hline 2 & Sales in INR Crore & 2.5 & 3.5 & 4 & 5 & 6 & 7 & 8 & 10 & \\
\hline & How was Inventories reduced : & & & & & & & & & \\
\hline 1 & Enhance the quality of componene & & & & & & & & & \\
\hline 2 & Monitoring of long lead items & & & & & & & & & \\
\hline 3 & Implement KANBAN & & & & & & & & & \\
\hline 4 & Monitoring and control Excess pur & hase th & rough & ERP S & ystem & & & & & \\
\hline 5 & Vender Upgradation through conti & dal imp & rovem & lent. & & & & & & \\
\hline 6 & Cost Reduction through Value Eng & neering & & & & & & & & \\
\hline 7 & To enhance quality create vender 1 & b. Ven & ders $n$ & heet at & vender & premis & ses. & & & \\
\hline 8 & Implement KAIZEN and $5 \mathrm{~S}$ Phil & ophy in & Plant & & & & & & & \\
\hline 9 & Improve Production Process by re & youting & & & & & & & & \\
\hline 10 & Introducting small automations. & & & & & & & & & \\
\hline 11 & Conveyerise System in the Process & o minis & mise & onvel & on tim & & & & & \\
\hline 12 & Bought Out New modern technolo & machi & ine in & tool $r$ & om,Pre & ss shop & and $\mathrm{N}$ & Iolding & Shop & \\
\hline 13 & Mold and Press tools are made by & st Ven & iders( & Mothe & rson an & d Time & ex to & control & the val & ariation. \\
\hline 14 & Implement multi fixture automatic & esting 1 & machir & ne. & & & & & & \\
\hline 15 & Enhance the training time to the S & $\mathrm{ff}$ as $\mathrm{v}$ & ell as & Work I & Man & & & & & \\
\hline 16 & Hiring Good Acedemic record Tec & aical P & eople. & & & & & & & \\
\hline
\end{tabular}

Annexure 2 A: Transforming ABC CO- RM Inventory v/s sales reduction

\begin{tabular}{|r|l|r|l|l|}
\hline & vender Quality Rating & & & \\
\hline SN & VENDER & RATING & MATERIAL TYPE \\
\hline 1 & Sumi Motherson \&Radiant Polymer & $100 \%$ & Plastic & \\
\hline 2 & Magnawire P Ltd & $100 \%$ & Copper & \\
\hline 3 & Rupam Conductors & $100 \%$ & Copper & \\
\hline 4 & Hindustan Platinum P Ltd & $100 \%$ & Silver & \\
\hline 5 & Sundaram Dynacast,Ester,DSMN & $100 \%$ & Plastic & \\
\hline 7 & Hindustan New Tools & $100 \%$ & Sheet Metal & \\
\hline 9 & Veekay Incorporation & $100 \%$ & Sheet Metal & \\
\hline 11 & Excellent Tools & $100 \%$ & Sheet Metal & \\
\hline & (Few best vendors) & & & \\
\hline
\end{tabular}

Annexure2B: Transforming ABC Co -Vendor Upgradation, Quality, Inventory Improvements 
e) Implementing Lean Manufacturing (LM) \& Agile Manufacturing (AM):

Supplier performance criterion was modified by introducing new Purchase Policy, which among others focused on: price, quality, on-time delivery, and availability of required quantity. Lean manufacturing systems operating on a continuous improvement philosophy based on the removal of waste from the system in order to maximize the potential of four order-winning criteria (Hill, 1993, p. 42). This philosophy is being supported by the reduction of set-up times to allow the economic production of small quantities (Booth, 1996).

With the lean initiative, integration with suppliers provided $\mathrm{ABC} \mathrm{CO}$,the benefits of reduced business risks by joint $\mathrm{R} \& \mathrm{D}$ or joint investment in technology, decreased cost of inventory by sharing forecast and /or production schedule, improved product quality in lesser time by joint design of products, leading to more stable price on long term basis(Hines, 1996).

Recently, Cagliano et al. (2006) conducted a study on lean manufacturing adoption in 425 manufacturing firms. The results showed that lean manufacturing adoption has a strong association with the integration of information flows and external suppliers.

\section{FINDINGS}

As a result of management interventions in last one decade along with author, initiatives taken as explained above have given extra ordinary operational dividends evidenced below.

\subsection{At Vendors end:}

Performance evaluations: $\mathrm{ABC}$ co measures performance of vendors based on many parameters as given below. This is established as described earlier by coordination and conducting cluster meetings once in a month at each vendor's premises along with vendors of same cluster for common improvement advantage to all. Vendors moving up in assessment index have been awarded with increased volumes of orders and priority in payments.

Quality: All vendors were encouraged to get ISO 9001 certification to maintain quality standard. Most of ABC vendors were ISO9001 certified by year 2011.ABC CO's vendors were also working out strategies to improve quality of inputs from their vendor by introducing Quality Systems Certifications.

Cost: The materials cost will continue to be competitive through innovations, automations as per expectations of $\mathrm{ABC}$ co. Vendors were encouraged to buy latest automated machines, tools, software's to reduce operational cost.

Delivery: The materials by vendors are delivered as per schedule at price ordered conforming to $\mathrm{ABC}$ co quality standards. Most of vendors have computerized inventory management and connected with $\mathrm{ABC}$ on e mail.

\subsection{Special Initiatives Taken by ABC Plastic Components Vendors}

Machine utilization: Selecting and using the machine tonnage (plastic component) as per the mound size and shot weight of the component-a criterion adopted by vendors. This helped in reducing machine running cost per unit of component.

Mould redesign: Increasing the number of cavity in the mould, reduced the machine operation cost per unit.

Processing: Using hot runner mound helped reduce the runner weight, bringing down weight of component, consequently reduction in per unit cost.

Machine effectiveness: Reducing mould change over time decreased machine down time/ depreciation cost thus further bringing down operation cost per unit.

Material cost: Reusing the runner by installing on line grinder on the machine thus further reducing per unit materials utilization cost.

Operations: Vendors reduced the machine operation cycle time by using chiller, in the mould, thus indirectly reduction in operation cost.

Materials Mix: Vendors after trial runs, utilized scrap material using impact modifier.

Manhours: Vendors deployed automatic material loader in machine thus reducing manpower cost. .

\subsection{At ABC Co end: Actions taken}

Modernization of plants: $\mathrm{ABC}$ co initiated no of additional actions for internal process improvements implementing LM\& AM.Automated machines imported from Taiwan, 
USA, and China were installed in press shop, moulding shops, paint shops. Low cost automations were introduced in their state of art factories at Baddi (Himachal Pradesh), Sahibabad (UP); Neemrana (Rajasthan).This reduced internal manufacturing process rejections to almost zero as manual interface was eliminated. Assembly, testing processes were again fully automated importing machines from Germany reducing human error to large extent (Pokayoke). As explained earlier TQM activities involving people at all levels compounded quality improvements reducing process rejections gradually to less than $1.2 \%$ by 2010 (Annexure 1 ).

SCM rewamp: New purchase policy amongst many initiatives was introduced, which made vendors feel that they are part of $\mathrm{ABC}$ company to make it win win situation. With the help of BAAN (an ERP solution), the purchasing and payments were customized in favor of vendors and simultaneous control of accounts payable at $\mathrm{ABC}$ end.

EDI (Electronic data interaction): As soon as PO (Purchase order) is created and approved in BAAN, PDF format of PO (purchase order) is sent via e mail. As soon as materials are received from vendor and approved by Quality department engineer using BAAN integrated RqMan quality software, acceptance is sent to vendor. The accounts department examines the invoice and quality report as per PO terms and prepares a bill; the vendor receives the advice on mail. Finally as soon as payment is transferred to vendor's bank account though rtgs and message via e mail is generated and sent through BAAN to vendor.

PPC: The production planning and control hitherto done at factory levels was not dynamic in line with customers demand. $\mathrm{ABC}$ co $\mathrm{BOD}($ Board of Directors) decided to introduce APO( Advanced Planning Organization) at Corporate office close to marketing office, to do monthly factory MRPII( material requirement plan II) for demand of finished goods- MCB, MCCB, Luminares( CFL,lighting systems), Control gears, Switch gears, cables, wires, Energy meters etc. This was done live on BAAN systems as per pan India as well as overseas demand.

$L M$ \& AM: In fact, supplier integration was a major step in the lean manufacturing implementation strategy used by many companies including ABC CO (Black, 2007). Such initiatives of LM \& AM were made possible with implementation of EDI (ERP, emails, on line payment through bank).The research by Bozarth and Handfield (2008) corroborates that over 65 percent of purchasing documents (e.g. purchase orders, amendments, shipping notices and delivery schedules) are being replaced by electronic means (Stuart So, Hongyi Sun, 2010).

The research model developed by H. Sharifi, Z. Zhang, (2001) has been used recently; the effect is yet to be noticed. Its time taking and challenging process to complete the research for the exact domain of capabilities, the need ,the drivers, agility providers, the corresponding practices and the correct suitable ways of implementing and assessing the capabilities. Certain noteworthy steps taken are as under:

\subsection{Examples of Internal Initiatives}

Alternate materials: Reduction in raw material weight of plastic latch, a component of MCB, was achieved by using low density material e.g. nylon6 replacing M/SEster Industries Ltd material density $1.4 \mathrm{gm} / \mathrm{cc}$ with that of $\mathrm{M} / \mathrm{S}$ DSMN Nylon, density being $1.2 \mathrm{gm} / \mathrm{cc}$.

Redesigning: Component plastic latch of $\mathrm{MCB}$ was redesigned, using reduction in wall thickness. The weight was reduced by $8 \%$, net saving, Rs $1 /$ on cost price of Rs12/- or MCB BOM cost reduction by $1.6 \%$.

\section{CONCLUSIONS}

The quality initiative, modernization initiatives, process modifications through AM \& LM including vendor up gradation in last thirteen years has resulted in following remarkable gains at $\mathrm{ABC}$ co. Moreover system has been introduced and implemented with ongoing efforts, also demonstrated that framework for vendor selection/ assessment/ up gradation and Quality improvements has been developed for other companies to follow similar practices to bench mark with that of $\mathrm{ABC}$ co standards :

PO Time: The order to delivery time has decreased by: more than $30 \%$ 
BOM cost: The BOM cost has come down by: $9 \%$

Vendors Materials Acceptance: The acceptance Quality (ABC co acceptance of lots of BOM items by vendors) had improved by: $42 \%$.

The inventory (BOM items) level: This in general, has reduced (from 24 days of sales, DOS, to 7 days) by: $70 \%$

\section{IMPROVEMENTS}

Quality Levels: There was investment in new technology including installation of few new machines and low cost automation equipment. Company expected the payback period of three years for the new installed capacity. Production and quality personnel, as well as team members from SCM, marketing, finance, formed CFTs (cross function teams) and SGAs, reducing rejections in all processes . Rejections which went up to over $16 \%$ earlier was brought down to less than $1.2 \%$. The German collaborators also appreciated this level of quality conformance as it was as good as German quality level. Productivity went up more than 10 times as people were trained in modern methods of quality \& manufacturing through team work as per TQM philosophy. ABC co was producing by end of 2010, more than 100,000 MCBs per day.

SGA levels: The pilot project started as SGA (small group activities) has been adopted by close of FY 2009-10 as full-fledged methodology.

\section{RECOMMENDATIONS}

Based on our literature review, findings and conclusions to improve vendors performance the additional recommendations are in process of implementation as below:

Delivery Performance: In addition to implementations of purchasing policy and up gradation programme few more initiatives are needed.

For delivery performance enhancement, the vendor is developed near the factory and create hub as $\mathrm{ABC}$ co has done at Baddi, Neemrana and Haridwar plants. This has made $\mathrm{ABC}$ co, a premium brand in electrical industries, possible to use vendors on jit system like automobile industries (Maruti Suzuki India Ltd, Toyota etc.) keeping inventory down from 24 days to less than7 days of sales (DOS) .Due to variations in demand and long supply cycle time, the related uncertainty can be addressed by adopting AM techniques, which is just introduced.

Inventory management: $\mathrm{ABC}$ co has kept recent benchmark of 9 DOS inventory level for A class material, lesser for B \& C class items inventory and kept the inventory at least $3 \mathrm{DOS}$ at vendor end.

Cost Reduction:Using Value Engineering based reduction in cost has to be done as in $\mathrm{ABC}$ co, it was done by replacing the basic BOM material by using another new material(Distribution Board knob earlier it was in nylon 6 natural costing Rs5.30/piece, which was replaced by abs natural costing only Rs 3.25/piece)

Process Improvements: $L M$ and $A M$ : By way of waste reduction, time reduction, quick change over of dies and tools, automated machines and manufacturing lines, JIT, AM systems implemented. TQM philosophy: $5 S$ system, kaizen, kanban system, pokayoke or fool proofing were being implemented.

Other Factors: In addition to all ten parameters for vendor assessment, up gradation, the, companies must consider two more factors e.g. 11. Payment terms and 12.Self Inspection report for better framework for benchmarking. These two parameters have been added, which has made benchmarking reliable and comparable for other industries to follow.

\section{LIMITATIONS}

The logistics and purchasing policy, including in $\mathrm{ABC}$ co, has not been documented as yet in many Indian companies though some of them are working as MNC( multinationals) having JVs( joint ventures) in India and as MNC globally.

The policy documents related to purchase, quality audit, and capacity audit are available in few companies including $\mathrm{ABC}$ co, but are not in public domain for research work.

\section{REFERENCES}

[1] Agile manufacturing in the aerospace industry: an industrial viewpoint, Phillips, Mark. International Journal of 
Agile Management Systems1. 1 (1999): 17-22.

[2] Atul B. Borade, Satish V. Bansod, (2010),"Study of vendor-managed inventory practices in Indian industries", Journal of Manufacturing Technology Management, Vol. 21 Iss: 8 pp. 1013 158

[3] Agile manufacturing, Wikipedia.org.in, retrieved on 21.7.12.

[4] Booth, R. (1996), "Agile manufacturing", $\quad$ Engineering Management Journal, April.

[5] British Aerospace Airbus (1998), Market Evaluation, March, Bristol, UK.

[6] Black, J.T. (2007), "Design rules for implementing the Toyota Production System", International Journal of Production Research, Vol. 45 No. 16, pp. 3639-64.

[7] Bozarth, C.C. and Handfield, R.B. (2008), Introduction to Operations and Supply Chain Management, Pearson Prentice Hall, Upper Saddle River, NJ.

[8] Benneyan James c.,Use and interpretations of Statistical quality control Charts , International Journal for Quality in Health Care 1998; Volume 10, Number I: pp. 69-73

[9] Cook R L and Rogowski(1996)" Applying JIT Principles to continuous process manufacturing supply chain" Production and Inventory Management Journal, Vol 37, No1, pp12-17.

[10] Chan, F. T. S. (2003).Performance measurement in a supply chain. International Journal of Advance Manufacturing Technology, 21, 534-548

[11] Deming W. E. Quality, Productivity, and Competitive Position. Cambridge, MA: Massachusetts Institute of Technology Centre for Advanced Engineering Studies.

[12] Dougles C. Montgomery, 2003, Probability and statistics in engineering, 2003. ISBN-10: 0471240877 | ISBN-13: 978-0471240877.
[13] Deming W Edward (1988), Out Of Crisis (14 principles): ISBN 02625415732.

[14] Davies, T., "Effective supply chain management", Sloan Management Review, Vol.34No. 4, 1993, pp. 35-46.

[15] Davis, D., "Partnerships pay off", Manufacturing Systems, Vol. 12 No. 11

[16] EFFRA 2010, Research Priorities Executive Summary, retrieved from www.effra.eu on 25.7.12

[17] Fawcett, S.E., Magnan, G.M. and McCarter, M.W. (2005), "Benchmarking information integration in supply chain management: a multilevel approach", available at: www.business.uiuc.edu/Working_Paper s/papers/05 .0117.pdf (assessed March 15, 2008).

[18] Golhar D Y, Stamn C L and Smith W P (1990)" JIT implementation in Manufacturing Firms", Production and Inventory Management Journals, Vol 31, No2, pp. 44-8.

[19] 20.. Goldman, S.L., Nagel, R.N. and Preiss, K. (1995) Agile Competitors and Virtual Organizations-Measuring Agility and Infrastructure for Agility. Van Nostrand Reinhold, International Thomas Publishing, London.

[20] Goranson, H.T. (1999) The Agile Virtual Enterprise: Cases, Metrics, Tools.Quorum Books, Greenwood Publishing Group, Inc., USA.

[21] Goldsby, T.J., Griffis, S.E. and Roath, A.S. (2006). Modeling Lean, Agile, andLeagile Supply Chain Strategies, Journal of Business Logistics, 27/1, 5780.

[22] Harrison, A. (1997). From Leanness to Agility, Manufacturing Engineering, 79/6,257-260

[23] Hill, T. (1993), Manufacturing Strategy, 2nd ed., Macmillan Press Ltd.

[24] Hines, P. (1996), "Purchasing for lean production: the new strategic agenda", International of Purchasing and Materials Management, Vol. 32 No. 1, pp. 2-10. 
[25] H. Sharifi, Z. Zhang, (2001),"Agile manufacturing in practice - Application of a methodology", International Journal of Operations \& Production Management, Vol. 21 Iss: 5 pp. $772-$ 794

[26] ISO 9001, www.iso.org/iso/iso_9000, retrieved on 24.7 .12

[27] ISO 14001, www.iso-14001.org.uk, retrieved on 24.7.12.

[28] JIPM-TPM,Retreived on 25.7.12 from www.jipm.or.jp.

[29] James-Moore, S.M. and Gibbons, A. (1997), "Is lean manufacture universally relevant? An investigative methodology", International Journal of Operation \& Production Management, Vol. 17 No. 9.

[30] Kidd, P.T. (1994) Agile Manufacturing: Forging New Frontiers. Addison-wesley Publishing Company Inc., USA.

[31] Kaynak H (2003), "The Relationship Between Total Quality Management Practices and Their Effects on Firm Performance", Journal of Operations Management, Vol. 21, No. 4, pp. 405431.

[32] Kidd, P.T. (1995), Agile Manufacturing, Forging New Frontiers, AddisonWesley, London.

[33] Kaizen concepts, www.Kaizen Eye.com, Retrieved on 21.7.12

[34] Kaizen Concepts, www.kaizen institute of management, retrieved on 24.7.12

[35] Kuk, G. (2004), "Effectiveness of vendor-managed inventory in the electronics industry: determinants and outcomes", Information \& Management, Vol. 41, pp. 645-54.

[36] Retrieved from www. Kaizen Eye.com on 21.7.12(Site is supported by CII, India).

[37] Kazuo Wada(2004)," Kiichiro Toyoda and the Birth of the Japanese Automobile Industry: Reconsideration of Toyoda-Platt Agreement", The University of Tokyo,July 2004 , CIRJEF-28828.
[38] Kidd, P.T. (1995), Agile Manufacturing, Forging New Frontiers, AddisonWesley, London. Montgomery, J.C. and Levine

[39] Katayama, H. and Bennett, D. (1999). Agility, Adaptability and Leanness: a Comparison of Concepts and a Study of Practice, International Journal of Production Economics, 6061, 43-51.

[40] Krishnamurthy R. and Yauch C.A. (2007). Leagile Manufacturing: a Proposed Corporate Infrastructure, International Journal of Operations \& Production Management, 27/6, 588-604.

[41] Levy, P., Bessant, J., Sang, B. and Lamming, R., "Developing integration through total quality supply chain management", Integrated Manufacturing Systems, Vol. 6 No. 3, 1995, pp. 4-12.

[42] Langton, J. (1998), "Seattle falls on hard times as Boeing's fortunes plunge", The Sunday Telegraph, 6 December.

[43] Masaaki Imai,1986," The Key To Japan's Competitive Success" November 1, 1986 | ISBN-10: $007554332 \mathrm{X}$.

[44] Masaaki Imai,1997,"Gemba Kaizen: A Commonsense, Low-Cost Approach to Managemen"tISBN-10: 0070314462 ,ISBN-13: 978-0070314467,

[45] Mattias Hallgren, Jan Olhager, (2009) "Lean and agile manufacturing: external and internal drivers and performance outcomes", International Journal of Operations \& Production Management, Vol. 29 Iss: 10, pp.976 - 99903852.

[46] Mark Phillips, (1999),"Agile manufacturing in the aerospace industry: an industrial viewpoint", International Journal of Agile Management Systems, Vol. 1 Iss: 1 pp. $17-2269$

[47] Montgomery, J.C. and Levine L.O. (1996), The Transition to Agile Manufacturing \pm Staying Flexible for Competitive Advantage, ASQC, Milwaukee, WI.

[48] Monczka, R.M., Callahan, T.J. and Nichols, E.L., "Predictors of 
relationships among buying and supplying fir ms", International Jour nal of Physical Distribution \& Logistics Management, Vol. 25 No. 10, 1995, pp. 45-59.

[49] Martin Christopher. "Logistics and Supply Chain Management",Financial Times/ Prentice Hall; 4 edition (18 Nov 2010),ISBN-10: 0273731122,ISBN-13: 978-027373112248

[50] Mason-Jones, R., Naylor, B. and Towill, D.R. (2000). Lean, Agile or Leagile? Matching Your Supply Chain to the Marketplace, Int. J. Prod. Res., 38/17,4061-4070.

[51] Mohanty, R.P. and Deshmukh, S.G., "Use of analytic hierarchic process for evaluating sources of supply", International Journal of Physical Distribution \& Logistics Management, Vol. 23 No. 3, 1993, pp. 22-8.

[52] Mark Phillips, (1999),"Agile manufacturing in the aerospace industry: an industrial viewpoint", International Journal of Agile Management Systems, Vol. 1 Iss: 1 pp. $17-22$

[53] Naylor, J.B., Mohamed, M.N. and Danny, B. (1997). Leagility: Integrating the Lean and Agile Manufacturing Paradigms in the Total Supply Chain, MASTS Woridng Paper, 47. Republished in International Journal of Production Economics (1999), 62, 107-118.

[54] Norris, G. (1998), "Executive decisions", Flight International, 1 December.

[55] Noorul, A. Haq and Hannan G. (2006).Fuzzy analytical hierarchy process for evaluating and selecting a vendor in a supply chain model. International Journal of Advance Manufacturing technology, 29, 826-835.

[56] Ohno, Taiichi (1995) "Toyota production system beyond large scale productions, Productivity Press Inc, ISBN0-915299-14-3.

[57] Perry , James H. "Firm Behaviour and Operating Performance in Just In Time
Logistics Channels", Journal Of Business Logistics ,Vol 9, No 1,(1988),pp 19-33.

[58] Peter McCullen, Denis Towill, (2001) "Achieving lean supply through agile manufacturing", Integrated Manufacturing Systems, Vol. 12 Iss: 7, pp.524 - 533

[59] Stuart So, Hongyi Sun, (2010),"Supplier integration strategy for lean manufacturing adoption in electronicenabled supply chains", Supply Chain Management: An International Journal, Vol. 15 Iss: 6 pp. $474-487$

[60] Shewhart W. A. The Economic Control of Quality of Manufactured Product. New York: D. Van Nostand and Co., 1931.

[61] Sarode, A. D., Sunnapwar, V. K. and Khodke, P. M. (2008).A Literature review foridentification of performance measures for establishing a frame work for performance measurement in supply chains. International Journal of Applied Management and Technology, 6 (3), 241-287

[62] Saad, M. and Patel, B. (2006), "An investigation of supply chain performance measurement in the Indian automotive sector", Benchmarking: An International Journal, Vol. 13 Nos 1/20,pp. 36-53.

[63] Sharma, V., Sahay, B.S. and Sardana, G.D. (2008), "An empirical assessment of impact of SCMpractices on quality performance - a case of Indian automobile industry", Supply Chain Forum: An International Journal, Vol. 9 No. 1, pp. 28-41.

[64] Sang Wook Chung, Young Sung Seo, Won Young Yun, (2006),"Acceptance sampling plans based on failurecensored step-stress accelerated tests for Weibull distributions", Journal of Quality in Maintenance Engineering, Vol. 12 Iss: 4 pp. $373-396$.

[65] Sha DY, Che ZH (2005). Virtual integration with a multi-criteria partner selection model for the multi-echelon 
manufacturing system. Int. J. Adv. Manuf. Technol., 25(7-8): 739-802.

[66] Retrieved from www.supply-chain.org on 24.7.12,SCOR model,2006.

[67] Sahay, B.S., Gupta, N.D. and Mohan, R. (2006), "Managing supply chains for competitiveness: the Indian scenario", Supply Chain Management: An International Journal, Vol. 11 No. 1,pp. $15-24$.

[68] Sahay, B.S., Cavale, V., Rajani, R., Mohan, R. and Gupta, P. (2001), Supply Chain Management Practices in Indian Industries, Macmillan India, New Delhi

[69] Skapinker, M. (1998), "Please wait in departure lounge", Financial Times, 3

[70] Stuart So, Hongyi Sun, (2010),"Supplier integration strategy for lean manufacturing adoption in electronicenabled supply chains", Supply Chain Management: An International Journal, Vol. 15 Iss: 6 pp. 474 - 487

[71] Shingo, Shigeo (1989), A Study of Toyota Production System from an Industrial Engineering View point", Productivity Press, ISBN0-915299-17-8.

[72] Sconcepts, www.tqmi.com, retreived on 1.7.12

[73] Sahay, B.S. and Mohan, R. (2006), "3PL practices: an Indian perspective", International Journal of Physical Distribution \& Logistics Management, Vol. 36 No. 9, pp. 666-89.

[74] Talha M (2004), "Total Quality Management: An Overview", The Bottom Line: Managing Library Finances, Vol. 17, No. 1, pp. 15-19. 5.

[75] Toyoda Kiichiro, retrieved from www.toyota-global.com on 18.8 .12

[76] Vinodh, S., Sundararaj, G., Devadasan, S.R., Kuttalingam, D. and Rajanayagam, D. (2010). Achieving Agility in Manufacturing through Finite Element Mould Analysis: an Applicationoriented research, Journal of Manufacturing Technology Management, 21/5, 604-623.
[77] Walter Mary (1986)," Deming Management methods", ISBN 0399550003

[78] Womack James P, Jones, Daniel T and Roas, Daniel (1991) "The Machine that Changed the World: The story of Lean Production ", Harpet Business, ISBN 006-097417-6.

[79] Wallace, W.E. Jr (1985), "Present practice and future plans for MIL-STD781", Naval Research Logistics Quarterly, Vol. 32, pp. 21-6.

[80] Youssef, M.A. (1992), “Agile manufacturing: a necessary condition for competing in global markets", Industrial Engineering,December,pp.1820.

[81] Zhang, Z. and Sharifi, H. (2000), “A methodology for achieving agility in manufacturing organisations", International Journal of Operations \& Production Management, Vol. 20,No. 4, pp. 496-512. 